\title{
Blast from the Past: Hopeful Retrofuturism in Science Fiction Film
}

\section{Joe P. L. Davidson}

\begin{abstract}
Observing images of jetpacks, flying cars and space colonisation today provokes a contradictory reaction. On the one hand, such phenomena remain unrealised and unfamiliar in everyday life but, on the other, they are indexed in the contemporary cultural imaginary to a particular historical moment: the technophilic futurism of the mid-twentieth century. This paradoxical coming together of the future and the past is at the core of the retrofuturist impulse, or the conscious reprisal of disappointed visions of yesterday's tomorrows. In this article, drawing on a number of science fiction films, I argue that the return to past images of the future has a potentially hopeful function, playing a role in rejuvenating and renewing utopian desire in the contemporary world. After discussing the current literature on retrofuturism, I turn to the work of the great utopian scholar Ernst Bloch, whose account of the dialectic of hope and disappointment offers a productive means by which to understand the residual utopian quality of the technological futures of the twentieth century. On this basis, I analyse two recent science fiction films, Elysium (2013) and Tomorrowland (2015), that bring together retrofuturist imagery and a hopeful disposition.
\end{abstract}

\section{Keywords}

Ernst Bloch, Film, Retrofuturism, Science Fiction, Utopia

\section{Publication Information}

Davidson, J. P. L. (2019) 'Blast from the past: hopeful retrofuturism in science fiction film', Continuum, doi: 10.1080/10304312.2019.1668352. 
The iconic science fiction film Things to Come (1936), directed by William Cameron Menzies and written by H.G. Wells, culminates in a utopian vision of the city radically reformed. Viewers are offered a glimpse into the life of Everytown in the year of 2036 where the dreams of twentieth-century modernists have been fully realised. The city, constructed underground, is an entirely artificial environment, complete with a parabolic glass dome, pristinely curved earthscrapers plunging downwards and moving walkways weaving through the buildings. The sense of futurity evoked by the architectural achievements of Everytown is reinforced by the primary dilemma faced by its citizens: space travel. The grand plans of Oswald Cabal (Raymond Massey) to send two pioneers from Everytown to the moon are vigorously opposed by the artist Theotocopulos (Cedric Hardwicke), whose passionate speeches against unconstrained progress ultimately result in a revolt against space travel. The film climaxes with the "space gun" - surrounded by rebellious Everytowners - firing a spaceship into the starry night.

Viewing Things to Come today provokes a strange, contradictory reaction. On the one hand, despite the fact that the film was produced over eighty years ago, much of the utopian world it envisages has not come to pass. Of course, some aspects of Everytown, such as video phones and space travel, are now familiar. However, the sleek modernist city it imagines, in which everything is designed for human flourishing and all needs are met, remains alien to our experience, evoking the sense of estrangement that is so associated with science fiction (Suvin 1979). On the other hand, there is clearly something dated about the vision of the future depicted in the film. This is partly due to the grainy, black and white quality of the film. More profoundly, Things to Come's version of the future is, in the cultural imaginary, grounded in a particular historical moment. As one reviewer of a digitally restored version of the film released in 2013 notes, 'citizens live underground in massive tiered structures that strongly resemble Hyatt Hotels of the 1980s and wear outfits that suggest beachwear built out with gigantic 
shoulder pads' (Kehr 2013). In Fredric Jameson's terms, there is now something 'historical and dated' about 'streamlined cities of the future'; the 'utopian future has [...] turned out to have been merely the future of one moment of what is now our own past' $(1982,151)$. Things to Come envisions a future that is now past, its modernist marvels and dreams of space travel recalling the hopes of the mid-twentieth century.

It is this coming together of a sense of futurity and pastness that marks Things to Come, in the contemporary moment, as a retrofuturist artefact. Retrofuturism, in its most basic sense, refers to a disposition in which one is concerned with futures imagined in the past, images of the new that are now old, and 'yesterday's tomorrows' (Guffey 2006, 152). Alongside the modernist cityscape depicted in Things to Come, paradigmatic retrofuturist images include jetpacks, flying cars and space colonisation. As these examples suggest, retrofuturism is focussed on a very specific set of utopian visions: the technophilic futurism that emerged primarily in the United States and, to a lesser extent, Europe between the 1930s and 1960s. ${ }^{1}$ As Elizabeth Guffey has expertly surveyed, the embrace of technology as the key to a more fulfilled future was infused into popular culture in many ways in the mid-twentieth century: pulp fiction magazines such as Hugo Gernsback's Amazing Stories explored the possibilities of technology, World Fairs showcased the "world of tomorrow" (as the 1939 New York World's Fair was entitled), television shows such as The Jetsons (1962-63) and Gene Roddenberry's Star Trek (1966-69) dramatized everyday life in the coming age of space travel, and the perfect geometric curves of modernist architecture seemed to reach for the stars (Guffey 2006; Guffey and Lemay 2014). In today's world, to borrow Kathi Weeks's fecund phrase, these artefacts comprise an 'archive of the future' in which 'the dead past of the archive' and the 'not yet of the future' are brought together $(2015,750)$.

There is probably no better example of the activity of archiving the future than the subreddit on retrofuturism. This subreddit, which has almost three hundred thousand 
subscribers, contains thousands of images and videos of the 'fantastic, delusional dreams of our past' (r/RetroFuturism n.d). The vast majority of the posts focus on the period of the midtwentieth century and it includes a huge diversity of futuristic material, including buildings, vehicles, toys, novel and magazine covers, and advertisements. For example, one user has posted an image of a toy gun from the 1950s called the Hubley Atomic Disintegrator (u/The Frood 2019). This raygun-like device, featuring a shiny surface and multiple domes, evokes the sense of possibility, and danger, associated with the rise of nuclear power in the years after the Second World War. Another user has shared a black and white photograph of a Soviet jetpowered car from the 1950s, the GAZ-TR “Arrow”, a sleek silver vehicle complete with a glass dome, rocket-style wings and a shark fin (u/hashamean 2019). Unsurprisingly, Things to Come features amongst those artefacts collected on the retrofuturism subreddit, with users posting stills from the film (u/jaykirsch 2019) and its promotional poster (u/Galimesh 2018). The retrieval and display of the filmic text in the new context of the twenty-first century marks it with new meaning, underlining the strange temporal mixing between the past and the future that defines retrofuturism.

As the example of Things to Come indicates, science fiction film is a fruitful resource for retrofuturist imagery. The classics of the genre, from Metropolis (1927) to 2001: A Space Odyssey (1968), are touchstones for retrofuturism. However, a shift occurred in science fiction film from the 1980s onwards. At this point, films ceased to only depict the cutting-edge dreams of the moment in which they were articulated and also revisited past images of the future. Beginning with Blade Runner (1982), science fiction film became increasingly, if not exclusively, defined by a retrofuturist disposition, recycling imagery that - either explicitly or implicitly - evokes visions of the future that are indexed to a particular historical moment (Bruno 1987; Guffey 2006; Graham 2016). Such films both embody the futurism of the midtwentieth century but also reflect on it, offering an interpretation of the act of reprising old 
dreams of unfulfilled futures. Put more precisely, retrofuturism in science fiction film refers to the conscious use of a repertoire of images of technology, architecture and design, as well as intertextual references to other cultural artefacts, that are indexed in the cultural imaginary to the futurism of the mid-twentieth century with the aim of reinterpreting, recontextualising and reworking the meaning of yesterday's tomorrows in the present.

In this article, drawing on a number of films exhibiting a retrofuturist impulse released in recent decades, including the Men in Black franchise (1997-2019), The Hunger Games series (2012-2015), Elysium (2013) and Tomorrowland (2015), I examine the function of the fascination with old images of the future in the contemporary cultural context. More specifically, I suggest that retrofuturism has a hopeful function. That is, through the retrieval and presentation of unrealised dreams of the past it is possible to renew the utopian impulse, recuperating the residual power of old images of the new to reformulate our understanding of the future. To make this argument, I begin by discussing the current literature on retrofuturism, which has for the most part focussed on the conservative and critical functions of retrofuturism. Then, utilising the work of the great utopian scholar Ernst Bloch, I delineate the possibility of a hopeful form of retrofuturism, suggesting that his account of the rise of fascism offers a productive means by which to think about the theoretical potentialities and challenges of hopeful retrofuturism. On this basis, I offer interpretations of two recent films, Elysium and Tomorrowland, which each bring together the retrofuturist impulse and a hopeful disposition in a distinct way.

\section{Retrofuturism: Conservative, Critical and Hopeful}

It is easy to see why the return to past images of the future might have a conservative effect. The association of retrofuturism with the past implies a concern with stability and continuity, and thus an acceptance of the inequalities and oppressions of the contemporary world. For 
example, Scott Bukatman (1991), in one of the earliest academic accounts of retrofuturism, suggests that Disney's futuristic theme park attractions draw on images associated with the golden age of the future to cultivate a comforting sense of nostalgia. The technological marvels of futures past contain 'nothing [that] disturbs the stability of the white, heterosexual, middleclass, extended nuclear family', with yesterday's tomorrows acting as a cipher for contemporary relations of domination (Bukatman 1991, 63). Past visions of new worlds, in a fashion similar to Jameson's (1991) sense of nostalgia as a form of pastiche, offer a mirage of the future: they confirm rather than trouble, are familiar not strange, and represent sameness not change (Sharp 2011; Spigel 2013). The Men in Black franchise is interesting in this context. The series is rife with retrofuturist imagery, including the raygun-like weapons used by agents K (Tommy Lee Jones) and J (Will Smith), the pivotal role that the pavilion of the New York World's Fair 1964-65 plays in Men in Black (1997), and the presence of jetpacks and space travel in Men in Black 3 (2012). However, whenever members of the public make contact with the world of the future, the agents wipe their memory of the encounter using a pen-shaped "neuralyzer", replacing the original experience of something incredible with something mundane. As such, Men in Black is predicated on the invisibility and impotence of past dreams of technological futurism; they are separated from the contemporary world and have no effect on it.

Yet, Men in Black's playful pessimism, with its comforting version of yesterday's tomorrows, is not the only possible articulation of the retrofuturist impulse. William Gibson's (1993) appraisal of the critical potential of retrofuturism, which has been widely discussed in the literature on the topic, is of particular importance here (see Bukatman 1991; Latham 2009; Jenkins 2010; Guffey and Lemay 2014). In an essayistic short story called "The Gernsback Continuum", Gibson explores the travails of a photographer, named Parker, who is working on a 'raygun gothic' book entitled The Airstream Futuropolis: The Tomorrow That Never Was 
(1993, 38). Parker is tasked with photographing the forgotten futuristic architecture of the United States. The project, however, deeply disturbs Parker. He begins to hallucinate, catching sight of an alternative universe where the dreams of pulp fiction writers of the 1930s have been fully realised. The dreams of the 1930s, once seen from the vantage point of the 1980s, disgust Parker; they are not wondrous examples of human progress but harbingers of dystopia, evoking the 'sinister fruitiness of Hitler Youth propaganda' (Gibson 1993, 47). Parker's awareness of the horrors of technological modernity - 'pollution, the finite bounds of fossil fuels, [and] foreign wars' - means that the futurism of the past ceases to inspire (Gibson 1993, 47).

A recent example of the critical retrofuturism discussed by Gibson can be found in The Hunger Games series of films. The visual depiction of the Capitol region of Panem, with its shining skyscrapers and wide boulevards, recalls the classic visions of futuristic cities presented in Metropolis and Things to Come. In other words, the speculative architectural vision of the film series evokes a familiar, entrenched sense of what it means to be modern. Yet, as viewers, we are also privy to the economic and political conditions that make the city of the future possible: the exploitation and oppression of the districts that surround the Capitol. For example, District 12, the home of the series' protagonist Katniss Everdeen (Jennifer Lawrence), sends coal to the Capitol while its own people live in poverty and are reliant on antiquated methods of survival - a fact symbolised by the bow and arrow that Katniss uses to hunt.

One cannot understand the place of retrofuturism in the contemporary cultural imaginary without attending to its conservative and critical articulations. However, these forms of retrofuturism do not exhaust the power of images of yesterday's tomorrows. Alongside the critical and conservative functions of retrofuturism, a hopeful function can be discerned. Ernst Bloch's (1991) account in Heritage of our Times of the rise of fascism in Germany, written in the 1930s, is of particular importance here. The historical catastrophe of the triumph of Nazism is, prima facie, distant from retrofuturism in the twenty-first century. Yet, the dialectic of hope 
and disappointment articulated by Bloch in this account offers a valuable means by which to approach retrofuturism. Bloch's study is concerned with the way in which the Nazis appropriated revolutionary dreams from previous phases of class struggle in order to build their support in the 1920s and 1930s. This is best exemplified by the Nazis' use of the term "Third Reich”, which for Bloch has a 'genuinely revolutionary' history that stretches beyond its 'embezzlement' by the fascists $(1991,117)$. This revolutionary history is grounded in the chiliastic peasant movements of the medieval period, where the phrase embodied the hope for a 'restored paradise' or an age of complete material and spiritual fulfilment (Bloch 1991, 128). Bloch is clear that this hope was disappointed in its moment of articulation: the revolutionary peasants failed to bring heaven down to earth and the epistemological foundations of chiliasm were undermined over the course of the eighteenth and nineteenth centuries.

Despite the disappointment of chiliastic hope, it still retains a power for Bloch. Disappointment does not result in the complete death of the original hope. Instead, the experience of disappointment produces a sense of "unfinished business", a feeling of being kept in suspense: all the time that the imagined future fails to arrive, it continues to represent a state of affairs that is to-come (see also Levinas 2000). As Bloch suggests, 'precisely because so much of the past has yet to come to an end, the latter also clatters through the early dawnings of newness' $(1991,144)$. The Nazis were able to exploit the unfinished nature of the old dream of the "Third Reich"; the fact that the hope for a "restored paradise" was not fulfilled in the Middle Ages meant that it represented a lost future that called to be fulfilled in the twentieth century. That chiliastic hopes were not realised in their own time 'must not be allowed to conceal either the power of ancient dreams or the explosive force which $[\ldots]$ is still inherent within them' (Bloch 1991, 131). The tragedy of the 1920s and 1930s was that socialists were unable - by virtue of their 'cold, schoolmasterish, and merely economistic' propaganda - to claim the genuinely emancipatory content of past chiliastic dreams, thus allowing the fascists 
to utilise the stock of past dreams as a utopian cover for their racist exterminism (Bloch 1991, 118).

For Bloch, therefore, '[e]ven disappointed hope wanders around agonizing, a ghost that has lost its way back to the cemetery and clings to refuted images' $(1995,195)$. It is this spectral quality of disappointed hope that is of particular relevance to retrofuturism. The dialectic between hope and disappointment identified by Bloch also holds between the technological futurism of the mid-twentieth century and the retrofuturist aesthetics of the contemporary moment. It is clear, as critics such as Gibson emphasise, that the technophilic dreams of the mid-twentieth century have been disappointed. There is no longer a widespread belief that flying cars, jetpacks and rayguns are technologically possible; we doubt that these dreams are realisable (Guffey and Lemay, 2014). So, in a similar fashion to the chiliastic dreams of the Middle Ages, technological futurism has been deprived of its grounding in reality. However, the fact that these dreams are disappointed means that they mark cracks in history, or alternative pathways to new states of being that presented themselves to historical hopers but failed to come to pass. Technological futurism is an 'undischarged past' that retains the capacity to shape our horizons of hope, pointing it in new directions and piquing the imagination to go beyond the dominant coordinates of the contemporary historical moment (Bloch 1991, 308). The residual power of technological futurism, its unstable position between the has-been and the yet-to-come, has the potential to rejuvenate the desire for a better way of living in the present.

Indeed, the examples of retrofuturism already discussed have a latent utopian quality. This is most obvious in the case of the future city in Things to Come. The reprisal of images of this idealised city, on forums such as the retrofuturism subreddit, has a hopeful function insofar that it serves as a reminder that people once imagined the world otherwise, positing the possibility of a state of affairs that is radically better than both the moment in which it was first 
imagined and the world of today. Men in Black can also be understood in hopeful terms. The film series attempts to isolate retrofuturist images from contemporary society, carefully policing the boundaries between the mundane everyday world and the spectacular world of agents $\mathrm{J}$ and $\mathrm{K}$. Yet, in viewing the second world where jetpacks are fully functional and extraterrestrial travel is the norm, we are encouraged to imagine the contemporary world otherwise. The depiction of "what could have been?", if the dreams of the 1960s had been realised, cultivates an attentiveness to the limitations of our contemporary horizons; the failed hopes of the past contain a clue to the possibilities of today. Even The Hunger Games's dystopic retrofuturism contains a fleeting moment of utopian potential. The film series poses the question of whether the splendours of the Capitol are possible without the poverty of the districts. In other words, to adapt Gibson's (1999) famous phrase, the redistribution of the future in an egalitarian fashion acts as a hopeful horizon.

A concern should be raised here, however. It might seem that hopeful retrofuturism, at best, naively attempts to transplant irrelevant past visions into the present and, at worst, represents a dangerous attempt to revive justly discredited ideologies of technological utopia. So, hopeful retrofuturism would be naïve because there is no guarantee that past visions of the future will have a hold in the contemporary world; they may, instead, simply distract from developing a vision of the future adequate to the present (Spigel, 2013). To put this claim in Gustav Landauer's (2010) terms, each utopia, a vision of the new, is tied to a topia, a contained and delimited historical context. Hopeful retrofuturism is potentially dangerous because, as critical retrofuturism elaborates, technological utopianism is marked by its association with relations of domination (racism, sexism, anti-democratic technocratic elitism and so on). To give an obvious example, the dream of space travel was tied up with the imperialist projection of power on the part of the United States, with its military and cultural Cold War battles with the Soviet Union closely imbricated with the desire for the conquest of the "final frontier" 
(Kilgore 2003). Hopeful retrofuturism, it would seem, asks us to ignore the exclusions and inequalities that are coded into past versions of the future.

It is, of course, possible to imagine a form of hopeful retrofuturism that exhibits such problems. However, hopeful retrofuturism need not involve the claim that past technological dreams are directly relevant to the contemporary world and should be transposed into the present without question. A more complex negotiation between the hopeful contents of old visions and the pressures of present problems can be observed in contemporary hopeful retrofuturism. Bloch, again, offers a useful clue to the contours of this mediation between yesterday's tomorrows and today with his suggestion that 'socialism may pay respect to the dreams of its youth, it sheds their illusion but it fulfils their promise' (1991, 118). As this suggests, hopeful retrofuturism may approach past visions of technological futurism in a critical fashion, recuperating retrofuturist images, motifs and features that retain a hold on the world and discarding those that are no longer relevant, thus separating the unsustainable ideological content of old dreams from their emancipatory elements (see also Jameson 1979). For the remainder of this article, I discuss two films, Elysium and Tomorrowland, which articulate a hopeful form of retrofuturism but refuse to uncritically transplant past visions of the future to the present, with the former utilising retrofuturist imagery to elaborate an allegory of present political tensions and the latter's retrofuturism aimed at evoking a sense of wonder and possibility.

\section{Elysium: Allegory, von Braun's Spacecraft and the Earthrise Photograph}

Since the release of District 9 in 2009, Neill Blomkamp has established himself as one of the most politically aware contemporary science fiction filmmakers, with his films raising questions of racism, inequality and migration. Blomkamp's Elysium, a big-budget Hollywood production starring Matt Damon and Jodie Foster released in the summer of 2013, is no 
exception to this. The film, set in the year 2154, imagines a world where the superrich have evacuated Earth to live on a luxurious space station called Elysium. The vast majority of the world's population remain on a dystopian Earth that is riven by poverty, in a state of environmental collapse, and controlled by a brutal robotic police force. The inequality between the two worlds is demonstrated most clearly in the film in terms of healthcare: whereas the Elsyians have access to Med-Bays that can cure almost any illness, hospitals on Earth are overcrowded and lacking in basic medicines. It is this inequality that drives the drama of the film, which centres on the desperate attempts of Max (Matt Damon) to reach Elysium's MedBays after he suffers an industrial accident that leaves him with only five days to live on Earth.

Of particular importance, for our purposes, is the way in which retrofuturism informs the visual representation of the two worlds of Elysium and Earth. Elysium is a rotating wheel space station, or a circular structure with spokes that orbits Earth. That the space station of the Elysians takes this distinctive form is significant given the place of the rotating wheel space station in the cultural imaginary. This speculative extra-terrestrial structure was made famous by the German-American space scientist Wernher van Braun in the 1950s in a series of articles in Collier's Magazine and subsequently featured in Disney's popular film Man in Space (1955) (Clément, Bukley and Paloski 2007). Importantly, von Braun's design provided the model for the space station Discovery One in Stanley Kubrick's 2001: A Space Odyssey (1968). The revival of the iconic image of the rotating space station in Blomkamp's film recalls the golden age of space travel and suggests that a retrofuturist impulse is at work in Elysium. ${ }^{2}$ More significantly, however, von Braun's design is particularly appropriate given the wealth and power of the spacecraft's inhabitants. It should be remembered that von Braun was central to both Nazi Germany's rocket programme and the Cold War efforts of the United States. His spaceship is thus the fruit of the webs of economic, military and scientific power that constituted what Dale Carter (1988) calls the "rocket state". The dystopic 2001, and its arbitrary 
and controlling android Hal 9000, reinforces this association between the rotating wheel space station design and authoritarian forms of power. So, the corrupt, illegitimate and exorbitant power of the Elysians is indexed to the cultural genealogy of their spacecraft.

Now, it might seem that Elysium functions in a similar way to the critical retrofuturism of The Hunger Games, with the impoverished and exploited Earth acting as a condition of possibility for the wealth and power of the Elysians. Matters are, however, more complicated in Blomkamp's film. The first retrofuturist image of von Braun's spaceship is brought into conflict with a second retrofuturist image, which has quite different cultural connotations. At the beginning of the film, a young Max (Maxwell Perry Cotton), pictured gazing up at the distinctive circular structure of Elysium in the sky, is passed a locket by an aged Nun (Yolanda Abbud) who is caring for him. The locket contains a picture of Earth. This is not just any picture of Earth but one of the first pictures of the planet taken from space: the Earthrise photograph shot during the Apollo 8 mission in 1968. This photograph, which has been reprinted millions of times, had a profound cultural effect. As Denis Cosgrove notes, the Earthrise image embodied a simultaneous sense of 'global utopia and global destruction', suggesting, on the one hand, humanity and nature united as one but, on the other, the fragile and isolated position of Earth in the universe $(1994,289)$. The early environmental movement, for example, utilised the Earthrise image to signal a concern with the health of the planet and its inhabitants, demanding that technological progress be reconciled with the precious but precarious equilibrium of "Spaceship Earth" (Poole 2008).

In this way, the conflict between Elysium and Earth in the film is mediated by two retrofuturist images: the technocratic authoritarianism associated with von Braun's spacecraft and the caring disposition evoked by Earthrise. The latter works to critique the former. Despite the fact that Earth is constantly within their gaze, the Elysians fail to attend to the needs of Earth; they are content in their abandonment of the planet and its inhabitants. Yet, in 
Blomkamp's film, the division between Elysium and Earth, the rotating spacecraft and Earthrise, is not a tragic one. The film culminates with Max and the computer hacker Spider (Wagner Moura), having stolen the digital "keys" to Elysium from a billionaire, breaking into its computer system to reboot its coordinates. Max, looking at the Earthrise image in his locket and then beyond this to Earth itself, presses a button that makes all the inhabitants of the Earth citizens of Elysium, killing himself in the process. At this moment, fleets of Med-Bays exit Elysium to cure the people of the previously neglected planet. The hopefulness of Elysium emerges from the reconciliation of its two conflicting images of retrofuturism. The technological elitism represented by von Braun's spacecraft is tempered by the caring sensibility evoked by Earthrise. The utopian potentialities of new technologies, this suggests, is dependent on their distribution: the egalitarian impulse of Earthrise, the concern with the world as a whole, provides the basis for ensuring that technological advances result in a better way of living for all.

Following an established science fiction convention, Elysium imagines another world in order to make an argument about contemporary society: via the figurative portrayal of Elysium and Earth, the claim is made that technological progress should be informed by a drive to equality (Suvin 1979; Wiegandt 2017). Indeed, as a number of critics of the film noted, Elysium - in a manner that reinforces its retrofuturist orientation - recalls Fritz Lang's Metropolis, which similarly offered an allegory of class struggle via the depiction of a futuristic city (Foundas 2013; Lambie 2013). The allegorical nature of Blomkamp's film is blatant. It is clear to viewers that the film makes a critical claim regarding inequality in the contemporary world. However, it should be stressed that the obviousness of allegory in Elysium is partly dependent on Blomkamp's figurative play of retrofuturist images. The depiction of the rotatingwheel space station and the Earthrise photograph, representing the authoritarian tendency of cutting edge technology and a caring sensibility towards the planet and its inhabitants 
respectively, offers a productive resource for the elaboration of the film's claim that all people should be citizens of Elysium. There is an elective affinity between the meaning embedded in these images and the utopian statement of Elysium. The political subtext of the film is thus grounded in the familiar culture of the golden age of space travel in the 1960s, the presence of the latter reinforcing and enriching the former.

Elysium, however, in placing images of futures past in an allegorical context, makes a comment on the place of the retrofuturist impulse in the contemporary moment. The clarity of Elysium's allegorical form means that its use of retrofuturist images does not take a naïve or dangerous form. That is, the film does not suggest that the dreams of the past can be transplanted to the present in a straightforward fashion; the affinity between images derived from the futurism of the mid-twentieth century and the contemporary world is not an identity. No claim is made that von Braun-style space stations should be sent into orbit or that the Earthrise-inspired environmental movement has the answers to the problems of today. Instead, Elysium draws on the rich resources of retrofuturism to elaborate an axiomatic demand relevant to global inequality in the contemporary world. The principle that all people should be citizens of Elysium makes the claim that technologies that are of benefit to humanity should be distributed in an egalitarian fashion. The figurative way in which this principle is articulated means that it retains a high degree of openness. In other words, the return to futures past provides a way to open a dialogue on the institutional arrangements and social relations that would guarantee the fulfilment of the demand for the egalitarian distribution of technology. The film, by making a prescriptive demand on the audience via a detour through yesterday's tomorrows, encourages a process of rethinking the world in the light of the principle "Elysium for all". 


\section{Tomorrowland: Jetpacks, Space Travel and the Utopian Marvellous}

Tomorrowland is, in many respects, a quite different film to Elysium. The film, it seems, is a far cry from Blomkamp's "intelligent" science fiction film. Its director, Brad Bird, is best known for his animated children's films The Incredibles (2004) and Ratatouille (2007) and Tomorrowland is a family-friendly picture aimed at the broadest possible audience. The fact that Tomorrowland is a Disney film named after an attraction found in its theme parks in Orlando and Paris immediately made some critics suspicious (Wheatley 2015). Tomorrowland also deploys retrofuturist imagery in a far more brash fashion than Elysium. Its image of the world of tomorrow is explicitly predicated on Walt Disney's own speculative utopian city, the Experimental Prototype Community of Tomorrow, while reviewers noted that Bird created 'a retro-future world that captures the essence of the 1960s space race aesthetic at a glance' (Bishop 2015; see also Lang 2015).

Yet, despite all this, Tomorrowland, like Elysium, is notable for its 'intriguing interplay between different encodings of nostalgia', bringing together a diversity of retro-futurist images to provoke a hopeful reaction (Garner 2017, 296). Tomorrowland grounds the imagination of a better world in the past, drawing out the utopian possibilities of the technological futurism articulated in the 1960s. The film begins with the young Frank Walker (Thomas Robinson) arriving at the New York World's Fair in 1964 to enter his malfunctioning jetpack into an invention contest. The jetpack is the archetypical retrofuturist mode of transportation, symbolising both the hopes of the 1960s and their failure to come to fruition (Latham 2009). As indicated in relation to Men in Black, the World's Fair of 1964-65, as the final truly great global exposition and the last-gasp of the "innocent" techno-optimism of the post-war years, is a key retrofuturist event, encapsulating the hopes of the mid-1960s in its distinctive modernist architecture (Samuel 2007). Frank, at the Fair, meets a girl, an android named Athena (Raffey Cassidy), who gives him a mysterious " $T$ " pin. This pin acts as a passport into the city of 
Tomorrowland, a wondrous technological utopia complete with fully working jetpacks that wend their way through a sleekly designed cityscape. Tomorrowland responds to the indignant question of "where's my jetpack!?" by postulating its existence in a concealed utopian world (Wilson 2007).

At this point, we are brought back to the present and introduced to Casey Newton (Britt Robertson), a teenage girl intent on sabotaging the government's dismantlement of NASA's Cape Canaveral rocket launch pad. Casey engages in a guerrilla action in defence of an endangered future, nostalgically holding fast to an outdated ideal of space travel in order to maintain her optimistic disposition. Casey's old-fashioned faith in the future is rewarded when she is passed a "T" pin by Athena and, like Frank, offered a vision of the world of Tomorrowland. In Tomorrowland, to Casey's delight, space travel is no more remarkable than air travel in the world of today. Importantly, as the film progresses, it emerges that the cityscape experienced by Casey is an image from the past; it is a non-contemporaneous glimpse into something that once existed but no longer does. As the older Frank (George Clooney) informs Casey, the "T" pins were minted in the distant past in order to serve as an advertisement for Tomorrowland. Casey's pin is a relic, a 'semiotic ghost' containing 'bits of the cultural imaginary' (Gibson 1993, 44).

In the case of both the protagonists of Tomorrowland, the route to the future is through the past. Frank's ability to envision a new world of technological marvels is dependent on his direct experience of the hopefulness of the 1960s while Casey's utopian gaze is indexed to her anachronistic disposition. It is the fact that both Frank and Casey are 'late to the end of history', holding fast to the discredited hopes of the past, that allows them to imagine the world otherwise in the twenty-first century (Derrida 2006, 17). So, past images of the future contain a utopian excess: jetpacks and space travel embody the possibility of a world that is better than the present. However, Tomorrowland is far more vulnerable than Elysium to the charge that its 
hopeful retrofuturism simply shifts, in an illegitimate fashion, the utopian dreams of the past to the present. As one critic notes, the film's 'central theme' is the 'enthusiastic embrace of technological utopianism as a remedy for the cultural angst that fuels human extinction as a self-fulfilling prophecy' (Hantke 2017, 747-748). For the film, it would appear, '[w]ith the earth heading for ecological disaster (global warming, war, famine etc.) this utopia could offer a solution' (Kermode 2015).

There are reasons, however, to question whether the retrofuturist technological utopia of Tomorrowland is posited as a model for the present. Tomorrowland, unlike Elysium, is resistant to an allegorical interpretation; it is difficult to discern a clear political principle or moral demand emerging from its play of retrofuturist images. Instead, the film exploits an alternative potentiality of the science fiction genre: its capacity to evoke a sense of wonder through the presentation of sublime and marvellous images of other worlds (Suvin 1979; Csicsery-Ronay, Jr. 2011). In Tomorrowland, knowledge of utopia is not to be gained through didactic descriptions of the future from figures of authority. Instead, both Frank and Casey gain knowledge of Tomorrowland through an immersive encounter in which they experience amazement at the technological marvels on display. The camera, in these scenes, flits between the utopian world and the awe-inspired expressions on the faces of Frank and Casey. Bird, utilising the expressive facial close-ups made famous by Steven Spielberg, offers a model to the viewer on how the gleaming cityscape of tomorrow should be responded to (Lee 2011). Tomorrowland, in these moments, engages in a presentational mode of cinematic expression; it uses retrofuturist imagery to produce a visually rich landscape with the aim of demonstrating the inspirational power of yesterday's tomorrows (Sobchack 1997).

Now, science fiction scholars have noted that the kind of spectacle witnessed by Frank and Casey is potentially authoritarian, functioning to overwhelm the viewer and deaden their capacity to creatively respond to the images on screen (Freedman, 2001; Bukatman, 2003). 
While a full critique of this claim is not possible here, I would like to suggest the possibility of an alternative reading suggested by the visual utopianism of Tomorrowland. Bird's film, by privileging the sense of wonder triggered by retrofuturism, participates in what Miguel Abensour calls the 'utopian marvellous' $(1999,132)$. For Abensour, the wonder of utopias, the way in which they break with the dominant horizons of the present and offer fantastic flights of the imagination, has an important effect, stating that: 'The point is not for Utopia [...] to assign "true" or "just" goals to desire but rather to educate desire, to stimulate it, to awaken it - not to assign it a goal but to open a path for it' $(1999,145)$. Wondrous images of otherness pique people not to desire this or that vision of utopia but simply to 'desire otherwise' (Abensour 1999, 146). Tomorrowland, by foregrounding the awe experienced by Frank and Casey, suggests that we return to futures-past not for answers to the predicaments of the present but rather to inspire us to think the world anew: the image of Tomorrowland acts as a springboard rather than a model. It is not the contents of past utopian visions that is of value in Tomorrowland but the affective reaction that they provoke, namely an openness to the future and the utopian possibilities that it presents.

That Tomorrowland fosters a liberatory rather than repressive response to the images on screen is given support by the montage scene at the end of the film, which offers an implicit critique of the technological utopianism that has defined Tomorrowland up to this point. Frank and Casey, having wrestled control of Tomorrowland from its villainous governor David Nix (Hugh Laurie), decide to restart the programme of sending out evangelists for the future into the world, each equipped with "T" pins to be passed to optimistic dreamers. In the montage, a great diversity of people of many races and genders, from all over the world, are approached by the new cohort of ambassadors for Tomorrowland and granted full access to its wonders: a musician, a scientist, a conservationist, a community worker, a judge, an artist, a mathematician, an engineer, a ballerina and so on. The film does not tell us what future these 
figures will build; it is left open-ended what the rich visual spectacle of Tomorrowland will inspire them to do and, implicitly, the viewer to do. However, the constellation of figures suggests a move beyond technological utopianism towards a more environmentally conscious and humanistic future, tempering the techno-optimism of 1960s futurism. So, via a detour through a wondrous reconstruction of yesterday's tomorrows, the future comes to be defined by a new openness.

\section{Retrofuturism and the Rebirth of History}

By way of conclusion, it is worth considering a figure that has remained at the margins of the presentation thus far: the so-called "end of history". Retrofuturism, as others have recognised, is grounded in the sense of historical closure that emerged in the West in the 1970s and 1980s. The anticipation of unlimited technological progress was undermined at this moment; 'the oil crisis, the recession of the mid- to late 1970s, and environmental disasters [...], all prompted widespread questioning of technology's benefits' (Guffey and Lemay 2014, 436). As such, it became increasingly difficult to postulate a technologically-saturated form of utopianism. Indeed, visions of a better future of all kinds began to decline at this moment, with the utopian impulse shrivelling in the face of the fall of the Berlin Wall and triumphant neoliberalism (Traverso 2016; Aronson 2017). Retrofuturism, even of the hopeful kind discussed here, recognises that images of the future articulated in the mid-twentieth century are discredited in the contemporary world, more likely to be invoked ironically than taken seriously as possible solutions to the problems facing humanity. Indeed, precisely what makes retrofuturism retro is that it understands that the utopias it draws upon are old fashioned, anachronistic and untimely.

Yet, there is also a sense, as both Elysium and Tomorrowland suggest, that retrofuturist images may help to break the sense of historical closure that has enveloped the cultural imaginary since the 1970 s, positing that latent utopian potentialities within old images of the 
future can reshape the horizon of expectation in the present. In fact, there is an elective affinity between hopeful retrofuturism and the contemporary cultural conjuncture. The late 2000 s and 2010s mark, in Alain Badiou's (2012) words, a "rebirth of history", with the global financial crisis of 2008, the uprisings in the Arab world of 2011, the return of contentious politics to Europe, and the rise of "populist" parties of the left and right suggesting a rupture with Francis Fukuyama's famous declaration of the "end of history" in 1989. Of course, this new moment of historical openness has not led to a revival of discourses of hope alone; many of the possibilities it contains are dystopian rather than utopian. It is, however, no accident that both Elysium and Tomorrowland were produced in the post-2008 world. The retrofuturism of these films - like many other utopian texts - articulates the hopeful potentialities of the contemporary moment, using past images of the future to explore possible futures. This does not mean that all current retrofuturism is hopeful, nor that conservative and critical articulations of the retrofuturist impulse can be dismissed. Nevertheless, hopeful retrofuturism, as it manifests itself in both Elysium and Tomorrowland, is of particular importance insofar that it mediates between the end of history and its rebirth. In the aftermath of the "end of history" - that historical period that placed a veritable 'taboo [...] on the future' - we are bereft of contemporaneous images of the future (Benjamin 2006, 35). In this context, it is no surprise that the future is rerouted through the past in hopeful retrofuturism: the past provides one of the few ways to address the utopian possibilities of the present. 


\section{Notes}

${ }^{1}$ As such, retrofuturism should be differentiated from other cultural movements focussed on yesterday's tomorrows. Steampunk, for example, is primarily concerned with the future as imagined in the Victorian moment rather than the mid-twentieth century (see Guffey and Lemay, 2014).

${ }^{2}$ Unsurprisingly, the retrofuturist comedy Space Station 76 (2014), which parodies the dreams of the future articulated in the 1970 s, is set on a rotating wheel space station. 


\section{References}

Abensour, M. 1999. "William Morris: The Politics of Romance." In Revolutionary Romanticism, edited by M. Blechman, 125-161. San Francisco: City Lights Books.

Aronson, R. 2017. We: Reviving Social Hope. Chicago: The University of Chicago Press.

Badiou, A. 2012. The Rebirth of History: Times of Riots and Uprisings. London: Verso.

Benjamin, W. 2006. “Central Park.” In The Writer of Modern Life, edited by M.W. Jennings, 134-169. Cambridge: Belknap Press.

Bishop, B. 2015. "Tomorrowland review." The Verge, May 17. https://www.theverge.com/2015/5/17/8612667/tomorrowland-movie-review-disney-bradbird-damon-lindelof.

Bloch, E. 1991. Heritage of our Times. Cambridge: Polity.

Bloch, E. 1995. The Principle of Hope, Volume I. Cambridge: The MIT Press.

Bruno, G. 1987. "Ramble City: Postmodernism and Blade Runner." October 41: 61-74.

Bukatman, S. 1991. "There's Always Tomorrowland: Disney and the Hypercinematic Experience." October 57: 55-78.

Bukatman, S. 2003. Matters of Gravity: Special Effects and Supermen in the $20^{\text {th }}$ Century. Durham: Duke University Press.

Carter, D. 1988. The Final Frontier: The Rise and Fall of the American Rocket State. London: Verso.

Clément, G., A. Bukley and W. Paloski. 2007. "The Gravity of the Situation." In Artificial Gravity, edited by G. Clément and A. Bukley, 1-33. Hawthorne: Microcosm.

Cosgrove, D. 1994. "Contested Global Visions: One-World, Whole-Earth, and the Apollo Space Photographs." Annals of the Association of American Geographers 84 (2): 270-294.

Csicsery-Ronay, Jr., I. 2011. The Seven Beauties of Science Fiction. Middletown: Wesleyan University Press.

Derrida, J. 2006. Specters of Marx. London: Routledge.

Foundas, S. 2013. "Elysium review." Variety, August 1. https://variety.com/2013/film/reviews/film-review-elysium-1200569714/.

Freedman, C. 2001. "Kubrick's 2001 and the Possibility of a Science-Fiction Cinema." Science Fiction Studies 25 (2): 300-318.

Garner, R.P. "Tomorrowland: A World Beyond DVD review." Science Fiction Film and Television 10 (2): 294-298.

Gibson, W. 1993. Burning Chrome. London: HarperCollins.

Gibson, W. 1999. "The Science in Science Fiction”. Talk of the Nation, National Public Radio, November 30. https://www.npr.org/2018/10/22/1067220/the-science-in-science-fiction. 
Graham, S. 2016. "Vertical Noir." City 20 (3): 389-406.

Guffey, E. 2006. Retro: The Cultural of Revival. London: Reaktion.

Guffey, E., and K.C. Lemay. 2014. "Retrofuturism and Steampunk." In The Oxford Handbook of Science Fiction, edited by R. Latham, 434-450. Oxford: Oxford University Press.

Hantke, S. 2017. ““When I Was a Kid, the Future Was Different”: Corporate Utopianism in Brad Bird's Tomorrowland." The Journal of Popular Culture 50 (4): 743-760.

Jameson, F. 1979. "Reification and Utopia in Mass Culture." Social Text 1: 130-148.

Jameson, F. 1982. "Progress versus Utopia; Or, Can We Imagine the Future?" Science Fiction Studies 9 (2): 147-158.

Jameson, F. 1991. Postmodernism, or The Cultural Logic of Late Capitalism. London: Verso. Jenkins, H. 2010. “"The Tomorrow That Never Was" - Retrofuturism in the Comics of Dean Motter." In Comics and the City, edited by J. Ahrens and A. Meteling, 63-83. New York: Continuum.

Kehr D. 2013. "Things to Come is a Trip Back to the Retro-future." New York Times, June 28. https://www.nytimes.com/2013/06/30/movies/homevideo/things-to-come-is-a-trip-back-tothe-retro-future.html.

Kermode, M. 2015. "Tomorrowland: A World Beyond review." The Observer, May 24. https://www.theguardian.com/film/2015/may/24/tomorrowland-a-world-beyond-reviewgorgeous-flawed-utopia.

Kilgore, D.W.D. 2003. Astrofuturism: Science, Race, and Visions of Utopia in Space. Philadelphia: University of Pennsylvania Press.

Lambie, R. 2013. "Elysium and the Gap between Rich and Poor in Sci-fi Cinema." Den of Geek, April 11. https://www.denofgeek.com/movies/elysium/25176/elysium-and-the-gapbetween-rich-and-poor-in-sci-fi-cinema.

Landauer, G. 2010. Revolution and Other Writings. Oakland: PM Press.

Lang, B. 2015. "Tomorrowland Inspired by Walt Disney's Vision of Utopia, Epcot Center." Variety, April 22. https://variety.com/2015/film/news/tomorrowland-disney-ant-mancinemacon-1201477444/.

Latham, R. 2009. “Our Jaded Tomorrows.” Science Fiction Studies 36 (2): 339-349.

Lee, K.B. 2011. “The Spielberg Face.” Fandor, December 13. https://vimeo.com/199572277

Levinas, E. 2000. God, Death, and Time. Stanford: Stanford University Press..

Poole, R. 2008. Earthrise: How Man First Saw the Earth. New Haven: Yale University Press.

r/RetroFuturism. n.d. "RetroFuturism: For the fantastic, delusional dreams of our past." Reddit. https://www.reddit.com/r/RetroFuturism/.

Samuel, L.R. 2007. The End of the Innocence: The 1964-1965 New York World's Fair. New York: Syracuse University Press. 
Sharp, S. 2011. "Nostalgia for the Future: Retrofuturism in Enterprise." Science Fiction Film and Television 4 (1): 25-40.

Sobchack, V. 1997. Screening Space: The American Science Fiction Film. Second Edition. New Brunswick: Rutgers University Press.

Spigel, L. 2013. “Postfeminist Nostalgia for a Prefeminist Future.” Screen 54 (2): 270-278.

Suvin, D. 1979. Metamorphoses of Science Fiction. New Haven: Yale University Press.

Traverso, E. 2016. Left-wing Melancholia: Marxism, History, and Memory. New York: Columbia University Press.

u/Galimesh. 2018. "Things to come, H.G. Wells." Reddit. https://www.reddit.com/r/RetroFuturism/comments/842i5m/things_to_come_hg_wells.

u/hashamean. 2019. "Soviet Car with Jet Engine, GAZ-TR "Arrow" 1954." Reddit. https://www.reddit.com/r/RetroFuturism/comments/azr5ir/soviet_car_with_jet_engine_gaztr_ arrow_1954/.

u/jaykirsch. 2019. "1936: Iconic still shot from Things to Come by H.G. Wells." Reddit. https://www.reddit.com/r/RetroFuturism/comments/apihih/1936_iconic_still_shot_from_thin gs_to_come_by_hg/.

u/The Frood. 2019. "Hubley Atomic Disintegrator - 1950s." Reddit. https://www.reddit.com/r/RayGunRepository/comments/avs6ai/hubley_atomic_disintegrator_ 1950s.

Weeks, K. 2015. "The Vanishing Dialectic: Shulamith Firestone and the Future of the Feminist 1970s." The South Atlantic Quarterly, 114 (4): 735-754.

Wheatley, C. 2015. "Tomorrowland: A World Beyond review." Sight and Sound, May 23. https://www.bfi.org.uk/news-opinion/sight-sound-magazine/reviews-

recommendations/review-tomorrowland-world-beyond.

Wiegandt, K. 2017. "Futurology, Allegory, Time Travel: What Makes Science Fiction Fascinating." In The Fascination with Unknown Time, edited by S. Baumbach, L. Henningsen and K. Oschema, 273-292. Basingstoke: Palgrave Macmillan.

Wilson, D.H. 2007. Where's My Jetpack? London: Bloomsbury. 